\title{
Power and Change in the US Cataloging Community
}

\section{The Case of William E. Studwell's Campaign for a Subject Cataloging Code}

\author{
Steven A. Knowlton
}

The US cataloging community is an interorganizational network with the Library of Congress (LC) as the lead organization, which reserves to itself the power to shape cataloging rules. Peripheral members of the network who are interested in modifying changes to the rules or to the network can use various strategies for organizational change that incorporate building ties to the decision-makers located at the hub of the network. The story of William E. Studwell's campaign for a subject heading code illustrates how some traditional scholarly methods of urging change-papers and presentations_are insufficient to achieve reform in an interorganizational network, absent strategies to build alliances with the decision makers.

The reasonable man adapts himself to the world: the unreasonable one persists in trying to adapt the world to himself. Therefore all progress depends on the unreasonable man.

Steven A. Knowlton (steven.knowlton @memphis.edu) is Collection Development Librarian at the University of Memphis.

Submitted August 22, 2013; tentatively accepted pending minor revision November 4, 2013; revision submitted November 19, 2013; accepted for publication January 23, 2014.

The author is grateful to Perveen Rustofram for introducing him to the idea of interorganizational networking, and to William Studwell, Lois Chan, Michael Gorman, John Hostage, Sheila Intner, and Mary K. Pietris for sharing their memories.
—George Bernard Shaw ${ }^{1}$

I came in and said I wanted to help. Dead silence. "Who sent you?" the committeeman said. I said, "Nobody." He said, "We don't want nobody nobody sent."

-Abner Mikva ${ }^{2}$

T n some ways the early 1990s was a time of wonders, in the wider world and in 1 libraries: as long-standing international tensions eased, library patrons began to enjoy expanded access to materials via online services. These anni mirabiles gave hope to the long-cherished dream of a maverick cataloger, as William E. Studwell wrote, "If two incredible occurrences like the dissolution of the Soviet Union and an agreement between Israel and the Arabs can take place, a much more attainable goal like a subject code is well within the realm of possibility." For all his hope, however, Studwell acknowledged that "ignorance, apathy, and negativism" on the part of librarians had all but crushed his aspirations. ${ }^{3}$ Although Studwell strove mightily to persuade the library community to adopt his idea, his efforts were ultimately fruitless. 
An examination of Studwell's campaign for a subject heading code will reveal that mere ideas, no matter their worth, cannot succeed in the face of an interorganizational network that requires knowledge of and access to decisionmakers to implement change. The nature of the US cataloging community and its centers of power can be illuminated by studying its structure and exploring how Studwell failed to persuade those who most needed to be persuaded.

Sociologists who study power relationships classify them according to the locus of power-it may reside in an individual, be latent in a social structure, or be made manifest via hierarchy. ${ }^{4}$ However, none of the classic descriptions of such relationships applies exactly to the community of libraries that shares cataloging data in the United States. It might formally be described as an "interorganizational network" that is "characterized by recurring exchange relationships among a limited number of organizations that retain residual control of their individual resources yet periodically jointly decide over their use. ${ }^{\prime 5}$ Many libraries, serving unique communities of users, may develop their own cataloging data that are shared freely with other libraries in the expectation that they will be able to use data generated by their partners when the need arises; other libraries simply use the records on offer without contributing any of their own.

However, unlike in most nonlibrary networks, the participants in shared cataloging are not on equal footing in defining the terms of their interactions. For reasons of history and economics, the largest participant in the networkthe Library of Congress (LC) - dominates the discussion about how cataloging data are to be formatted. In the case of the most commonly used subject access vocabulary, the Library of Congress Subject Headings (LCSH), LC maintains complete control over the list of headings. ${ }^{6}$ Libraries are free to adapt the records for local use (see Sanford Berman's collected writings for examples of this approach). ${ }^{7}$ However, libraries that create records for use by other institutions using LCSH typically comply with the standards established by LC for the subject headings because other libraries in the network often expect the records to resemble LC records and have configured their systems to operate using LC-compatible records.

Initiating and sustaining change within the interorganizational network that is the shared cataloging community presents numerous challenges-some that are described in the literature about organizational change, and others that can be understood using the tools of network theory. This study analyzes a case of failed organizational change to illuminate the challenges of organizational change within a network dominated by a single partner that has a monopoly on the terms of exchange. The campaign by William E. Studwell to persuade LC to adopt a subject cataloging code illustrates the limits on network partners imposed by LC's control over data formatting rules.
This paper will begin by describing the structure of interorganizational networks and will show how the US cataloging community functions as one. It will then explore the ill-fated attempts by Studwell to reform LCSH and examine why an understanding of power and change are crucial to a reformer's chances of success.

\section{The Nature of Interorganizational Networks}

The interorganizational network is a strange beast - to a business writer, it is "neither market nor hierarchy," but a librarian might consider it neither a hierarchy nor a vendor. ${ }^{8}$ The formation of interorganizational networks has many motivations, including seeking cost savings, maintaining access to resources, and developing skills among the staff of member organizations. However, Powell points out that, unlike other forms of resource exchange, in interorganizational networks "the sharing of information ... often leads to the emergence of common values." The interorganizational network, then, has a self-sustaining quality: as members come together to achieve a common purpose, their endeavors create a set of common values that inform future activities.

Despite common goals and values among members of a network, there is not equality of influence on the network's rules and activities. Given that "governance may have definite impacts on network outcomes," anyone working within a network must understand its power structure-which, in the shared cataloging network, is "lead organization governance." ${ }^{\prime 10}$ As Provan and Kenis write, "in lead organization governance, all major network-level activities and key decisions are coordinated through and by a single participating member, acting as a lead organization. Thus, network governance becomes highly centralized and brokered, with asymmetrical power."11 In the case of the US cataloging network, LC plays an important role in developing cataloging rules and acts as a the primary gatekeeper of the distribution of cataloging metadata within the network, while reserving to itself the ability to make changes to the controlled vocabulary and authorities.

Governance, however, can be distinguished from leadership. Governance concerns "how the network is structured."12 Leadership is "making things happen," and may occur within or without the formal structures of governance. ${ }^{13}$ For things to happen, a leader (whether a person or an organization) is required to bring the governing body to agreement that the initiatives under discussion are beneficial to the members of the network - and in the case of a lead organization-governed network, that the proposals will redound to the good of the lead organization in particular.

A would-be leader from outside a lead organization is faced with multiple challenges. In addition to the ordinary challenges facing all leaders-correctly analyzing situations, 
developing appropriate solutions to problems, and implementing them throughout a bureaucracy - those on the periphery of a network must also somehow penetrate the barriers to access presented by the lead organization's governance model. This task is made doubly difficult not only by the formal structures inhibiting leadership from the margins, but also by the informal (but no less powerful) interactions in which those who hold power are able to control the very discussions about their control.

The formal structures of lead organization governance require that someone, often a person highly placed, must approve of initiatives led by outsiders. But even bringing those initiatives to the attention of such powerful actors is hindered by the nature of power relations within networks. In a meta-analysis of studies on interorganizational networks, Brass et al. found that the centrality of a decisionmaker within the network is more indicative of his power to influence decisions than is any behavior he exhibits. ${ }^{14}$ Bradshaw and Boonstra point out that organizational power is self-perpetuating: "In organizations, the distribution of power is often characterized by stability. This stability results from a commitment to decisions concerning the realization of the business strategy, the structuring of the organization, and the distribution of power that emerged from the past." ${ }^{\prime 5}$ Compounding this concentration of power are the tools used to variously include or exclude those seeking to influence decision-makers. Hardy and Clegg note, "A variety of barriers are available to the more powerful groups to prevent subordinates from fully participating in the decision-making process through the invocation of procedures and political routines. The use of these mechanisms has been termed non-decision-making, because it allows the more powerful actors to determine outcomes from behind the scenes." 16

One seeking to be a change agent in an interorganizational network must identify where power is truly located and build ties that allow one to bypass the institutional barriers erected to keep marginal network members out of the decision-making process. Yukl identifies a variety of tactics for persuading power brokers to make a change, but notes that "change agents who have political power and skill are more likely to be successful in initiating and facilitating major changes in large organizations." ${ }^{.17}$ Yukl's list of tactics (in descending order of "perceived effectiveness" according to a poll of managers) includes rational persuasion, inspirational appeals, collaboration, consultation, appraisal, coalition tactics, ingratiation, pressure, exchange, and personal appeal.

When Studwell approached the cataloging community with his ideas for change, he lacked important ties to centrally located decision makers and misjudged the power of his ideas and the effectiveness of his presentation of the ideas. He began from a position on the periphery of the network and failed to make meaningful connections to those with power to implement changes; furthermore, his use of a limited number of tactics was hampered by his failure to apply the tactics in the ways that are known to be most effective.

\section{The US Cataloging Community as an Interorganizational Network}

Although the US cataloging community has been an interorganizational network for many years, it was not founded as one. The actions of LC and developments in technology have gradually created a series of incentives for libraries to rely on LC as the hub of a data-sharing network, which has become formalized more recently.

Cataloging in the US was systematized in the nineteenth century by numerous librarians working separatelyCharles Jewett, William Poole, Ezra Abbot, Charles Cutter, Frederick Perkins, Melvin Dewey and Mary Salome Cutler, K. A. Linderfelt, and others developed their own cataloging codes. ${ }^{18}$ An 1893 survey found at least seven different sets of rules in active use in American libraries. ${ }^{19}$ The profusion of codes gave way to a spirit of cooperation, and in 1908, the American Library Association (ALA) published a cataloging code that was widely adopted. ${ }^{20}$ The ALA code was for descriptive cataloging only and did not address subject headings. Subsequent descriptive cataloging codes have been adopted by ALA in conjunction with other Englishspeaking library organizations. However, to date there is not a cooperatively developed code for creating subject headings. American catalogers still rely on subject headings formulated by LC or on rules promulgated by LC for devising new headings.

LCSH grew from a list of headings prepared by the ALA in 1895 and adopted by LC for its own use in $1898 .^{21}$ After LC began distributing its catalog cards to other libraries in 1901, the use of LC's subject headings - and therefore Cutter's rules-slowly became nearly universal. ${ }^{22}$

After 1901, use of LC cataloging copy grew exponentially. By 1914, 1,986 libraries in the United States and Canada were buying catalog cards from LC, and the number grew to 5,738 in 1935 , which represented a large majority of the libraries on the continent. ${ }^{23}$ In short order, the libraries of the United States had moved from an environment of many cataloging codes and philosophies to a monoculture of cataloging according to LC standards. As early as 1908, the ALA Cataloging Code was designed to conform to LC practices. ${ }^{24}$ Henderson remarked that "once LC had begun to issue some cards, the libraries expected it to fill all their cataloging needs." ${ }^{25}$ Later, the broad adoption of LC Classification (LCC) in larger libraries had much to do with "the simple fact that the LC symbols appeared more consistently and completely on Library of Congress printed cards," saving libraries the trouble of classifying their books according to Dewey Decimal or some other scheme. ${ }^{26}$ 
Libraries that were purchasing LC cards sought to maintain consistency by using LC's subject headings in their own original cataloging. There was public demand for LC to share the updated list of subject headings that had been adopted since the ALA list was published in 1895. LC had begun an internal authority file in 1898 and used it to prepare the first edition of Subject Headings Used in the Dictionary Catalogs of the Library of Congress in 1909. ${ }^{27}$ That list, renamed Library of Congress Subject Headings, has been through thirty-three print editions and is now mostly used as a data file accessible via the Internet.

For various reasons that have been explored elsewhere, LCSH evolved into a system "based on precedent and analogy rather than on formal rules." pointed out that some headings were "absolutely hilarious, outrageously offensive, or just plain mysterious. ${ }^{{ }^{29}}$ A large body of library literature criticizing LCSH accumulated over the years, often calling for LC to be more forthcoming about the methods of formulating headings or to develop formal standards for creating headings. ${ }^{30}$ The Vatican Library prepared a cataloging code that incorporated rules for creating subject headings on the basis of LC practice; however, an English translation was not available until 1948, and it was never presented as a guide for American catalogers. ${ }^{31}$

LC responded to such criticisms by publishing Haykin's Subject Headings: A Practical Guide, issuing the regular periodical Cataloging Service Bulletin, printing A Guide to Subdivision Practice, and eventually making public its internal Subject Cataloging Manual: Subject Headings (SCM). ${ }^{32}$ Through the 1960s and 1970s, LC committed itself to incremental changes that constituted "improvement of the list in its present terms. . . . This course provides the obvious advantages of orderly evolution. ${ }^{\text {"33 }}$ These improvements and publications were of immense practical value but did little to stanch the tide of criticism about the structure of LCSH.

For many years, use of LC's cataloging data was largely a take-it-or-leave-it proposition: a library could order LC's cards and use or modify them, but had no means to provide cataloging data or useful criticism back to LC. An attempt in the 1930s and 1940s to create a formal network for libraries to contribute cataloging data to LC foundered, largely on LC's reluctance to use many of the records contributed by partner libraries ${ }^{34}$ However, in the late 1960s, the development of the MARC format for computerized storage of bibliographic data, along with telephony-based data exchange, allowed for libraries to develop electronic networks for sharing cataloging records-the earliest, OCLC, was online in 1971 and immediately successful at increasing productivity and reducing costs. ${ }^{35}$ At this point, "LC made a defining shift in its approach to cooperative projects," using the OCLC database to share its serials records and allowing selected libraries to modify them for the use of all. ${ }^{36}$ The Cooperative Online Serials Program, or CONSER, was followed by cooperatives for name authority records (NACO) in 1977, subject authority records (SACO) in 1992, and bibliographic records (BIBCO) in 1995; collectively these networks are the Program for Cooperative Cataloging (PCC).

Although these cooperative efforts are, according to Wiggins, "very democratic in nature, with most members having voting rights," the rules by which records are created are those of LC. ${ }^{37}$ All proposals for changes to established authority records must be cleared by LC before they are used by other libraries in the program, and the creation of new records proceeds according to rules established by LC. Although libraries across the country take advantage of OCLC, and PCC members participate in shared governance of the cooperative, LC reserves for itself the power to "determine outcomes" in formulation of LCSH, as Hardy and Clegg have named this process.

As an interorganizational network, the cataloging community in the United States has at its center LC. An examination of the case of one librarian at the periphery of the network who sought to change the way the network operated will illustrate the institutional power to preserve prerogatives and the limitations on those who seek to be change agents.

\section{William E. Studwell's Campaign for a Subject Heading Code}

To the reader perusing the cataloging literature of the 1980s and 1990s, one name appears repeatedly in the tables of contents of numerous journals: William E. Studwell (1936-2010). In fact, Studwell was adjudged among the most prolific writers on library topics in each of those decades. ${ }^{38}$ Many of his papers were focused on a single topic: establishing a subject cataloging code, similar to the Anglo-American Cataloging Rules (AACR) for descriptive cataloging. Despite efforts so vigorous that Henderson characterized his activities as a "crusade," Studwell and those who participated in his lobbying had little effect on the institutional policies governing subject headings. ${ }^{39}$ His initial presentation of his ideas kicked off a brief period of debate, but interest waned quickly. Notwithstanding his copious output, Studwell has seldom been referenced by other authors, and a subject cataloging code has not yet been adopted. Studwell failed to form political relationships close to the core of the network, and his use of certain tactics, such as rational persuasion, inspirational appeals, and coalition tactics failed not only because of his distance from the center of power but also because his use of such tactics was often less adept than necessary.

\section{William E. Studwell's Background and Career}

Studwell began his academic career at the University of Connecticut, where he studied history as an undergraduate 
and earned a master's degree in European history. His ability to speak and read Russian led to a position at LC's Soviet and Russian division, and while working there he earned his master of library science degree from Catholic University in 1966. In 1970, he started as head cataloger at Northern Illinois University in DeKalb, becoming principal cataloger in 1983 and earning promotion to full professor; he enjoyed a long career in cataloging before retiring in 2001. He made many contributions to the profession, such as designing the index for the 18th edition of Dewey Decimal Classification, serving on many committees of professional organizations, editing publications, presenting talks, and writing both a book of exercises for training catalogers and a practical guide for subject cataloging of films and videos. ${ }^{40}$ Most prominent of his professional activities was his writing: by the time he retired, Studwell had published 3 monographs and 119 papers on topics of librarianship. In addition to his professional interests as a librarian, Studwell wrote extensively on the lives of composers and songwriters, ballets and operas, and popular songs. He achieved a small measure of renown as one of the world's leading authorities on Christmas carols. ${ }^{41}$

Studwell's activism on behalf of reforming LCSH must be considered in the context of cataloging in the 1970s and 1980s. This period saw many profound changes to the way catalogers went about their work. The rules for descriptive cataloging had changed twice in a dozen years, with the second change (AACR2, implemented in 1981) requiring retrospective changes to thousands of catalog cards; the International Standard Bibliographic Description (ISBD) and its derivatives were introduced; and the first computerized catalogs went online.

Despite reforms in the administration of LCSH, discontent with the system remained strong among many catalogers. A brief survey of paper titles may provide some idea of the passions aroused by LCSH: "Subject Headings Trauma"; "Subject Headings Muddle"; "Poland is Not Yet Defeated, Or: Should Catalogers Rewrite History? With a Discourse on When is an Island Not an Island?"; "The End of Specificity"; "Coping with Subject Heading Changes"; "Subject Headings, Silly, American-20th Century-Complications and Sequelae-Addresses, Essays, Lectures"; "Library of Congress Subject Headings: Is Euthanasia the Answer?"; and "Can Subject Headings Be Saved?"42 In this environment, a self-described "gadfly" could see opportunities to put forth ideas for change that would find an accepting audience. ${ }^{43}$

\section{Studwell's Approach to LCSH}

By the early 1980s, Studwell was in agreement with those who called for change in LCSH, and he began to publish his views frequently in library journals. His first attempts at publicly advocating reform took the shape of a series of ten lengthy papers, published in Cataloging and Classification Quarterly between 1982 and 1987. Each paper proposed additions to the period subdivisions used for subject headings related to a geographic area (such as Ethiopia-Economic conditions-1889-1974). ${ }^{44}$ In these papers (often written in collaboration with colleagues), he proffered suggestions for more than 200 separate jurisdictions-each requiring research into the history and existing subject heading period subdivisions of a region. LC later adopted some, but not all, of his suggestions. It is interesting to note that Studwell's articles in this series consistently repeat that the "proposed additions given are suggestions ... . not to provide absolute answers, but to promote awareness of the incompleteness of LC's period subdivisions." ${ }^{45}$ There is no indication that Studwell contacted anyone at LC to propose new subdivisions.

\section{The Subject Heading Code: First Proposals}

Studwell's next, and most momentous, effort to reform LCSH was the proposal of a subject heading code: that is, a set of rules similar to AACR by which subject headings would be formulated and assigned. He was not the first librarian to make such a proposal, as he was careful to note. In 1944, Henry B. Van Hoesen proposed "Twelve Rules for Economy in Subject Headings," and in 1979, Sanford Berman published "Proposed: A Subject Cataloging Code for Public School and Community College Libraries." ${ }^{" 46}$ However, these efforts were practical suggestions to improve the practice of assigning headings; what Studwell proposed was a more thorough delineation of the principles underlying subject headings-a "comprehensive theoretical code" that would cover the philosophy, structure, and form of subject headings. Studwell's first publication of his proposal came in fall 1985, with 'Why Not an 'AACR' for Subject Headings?"47 In this paper, he outlined the past efforts of his colleagues and proposed a plan and process for creating a subject heading code (he favored collaboration between LC and other librarians, much as had been done in the creation of AACR); he also defended the usefulness of LCSH against those who favored abolishing it. Studwell acknowledged LC's efforts at sharing information regarding their practices, but averred, "This data is very useful, but unfortunately leaves too many questions unanswered. . . . What is really needed is a comprehensive set of guidelines designed to serve all aspects of subject cataloging and which are flexible enough to accommodate the seemingly unending requirements for change."

Over the next two years, Studwell followed up his initial proposal with papers aimed at convincing academic librarians and map librarians of the necessity for a subject heading code. ${ }^{48} \mathrm{He}$ also gave presentations at the Seminar on the Acquisition of Latin American Library Materials in May 
1987 and the Canadian Committee on Cataloging in October 1987. With the fervor of an evangelist, Studwell took his message to every audience that would hear him.

In December 1987, Studwell attracted massive attention to his idea by placing an article in American Libraries, the magazine distributed to all ALA members. ${ }^{49}$ In "The 1990s: Decade of Subject Access," Studwell asserted that the emerging technology of keyword searching would not alleviate the problems of subject access presented by the state of LCSH. He proposed that "with the formulation of a theoretical subject heading code, the third phase in the maturation of modern cataloging will be completed," the first two phases having been the rationalization of descriptive cataloging rules under AACR and the creation of LC's online authority files. Presciently, Studwell also described obstacles to the creation of a subject heading code. They included general resistance to change, a lack of foundational principles (like the Paris Principles which had been the foundation of AACR), and the heavy workload of LC's cataloging staff. He concluded, however, that a concerted effort from librarians outside of LC could relieve that institution of some of the effort and produce a subject heading code by the end of the twentieth century.

The primary rationale presented by Studwell for such a massive undertaking was that

despite some opinion to the contrary, the many retrieval problems of LC subject headings will not diminish with the increased use of computers to access materials. Keyword searching will aid somewhat in the subject-retrieval process, but it can by no means substitute for a logically structured, semantically effective subject-heading system that provides qualitatively accurate and quantitatively adequate headings for the spectrum of human knowledge.

To compensate for "the very heavy workload of LC's Subject Cataloging Division," Studwell volunteered "to serve as an intellectual clearinghouse external to LC to gather and preserve the ideas and suggestions others may contribute toward the betterment of LC subject headings. . . . If the clearinghouse activity does not appeal to some, the alternative avenues of publication or direct contact with LC are always available."

\section{Reaction to the Proposal for a Subject Heading Code}

Once Studwell had the library community's ear, reactions to his proposals came frequently in the next few years. Mary K. D. Pietris, chief of LC's Subject Cataloging Division, was allowed a response to his piece "The 1990s: Decade of Subject Access" on the same page in American Libraries. It seems that Studwell's paper had taken her by surprise; she even sounds a bit defensive:

The need expressed to the Library of Congress by its constituents has always been for LC to explain its principles and policies for creating and assigning subject headings. In response to this need, in the last three years the Library has published two editions of the Subject Cataloging Manual. .. . The Library plans to develop sections for the Manual that describe the basic philosophy of assigning headings and of creating new headings. ... The Library frequently raises issues for the consideration of the American Library Association through the ALA committee responsible for matters of subject access [the Subject Analysis Committee (SAC) ] . . . we also respond to issues brought to our attention by the Subject Analysis Committee. . . . We believe that our current practice of working with ALA's SAC is effective, and that a more complete Manual is needed. We are not aware of any needs relating to a code that the Manual will not satisfactorily fill..$^{50}$

Relatively early in his campaign for a subject heading code, Studwell reached a point of crisis, born largely from his politically naive approach. Recalling Bradshaw and Boonstra's admonitions that "the change agent must align with those in power and then influence them to desire and accept the changes," one can see that Studwell's approach of presenting a preformed idea that served as an implicit public criticism of LC was diametrically opposed to the successful approaches to change management identified by those who have studied organizational change. ${ }^{51}$ Studwell persisted for several more years, mostly through writing and speaking, and less so through political action.

Despite Pietris' reaction, other catalogers sided with Studwell. Intner (later a collaborator with Studwell on a monograph about cataloging film and videos) published "ASCR: The American Subject Cataloging Rules (Part 1)" in July 1988, and followed with "The Trouble with Harry: ASCR (Part 2)" in September. ${ }^{52}$ She not only proposed a name for the subject heading code, she suggested some of the principles to be used, such as defining terms used as subdivisions and creating a standard for the use of subdivisions. Most importantly, she suggested that a subject heading code should be based on observed search behavior among library patrons. Wajenburg's "The Future of Cataloging Standards," published in September 1990, also lauded Studwell's goal, but feared it might be "utopian."

Pietris had made very clear the method through which LC would consider proposals for a subject heading code: formal consideration by the ALA's Subject Analysis Committee. 
SAC, not to be confused with the Subject Authority Cooperative (SACO), is charged

to study problems and recommend improvements in patterns, methods, and tools for the subject and genre/form analysis and organization of library materials, including particularly classification and subject headings systems, and to provide liaison for those areas of interest between ... ALA and non-ALA organizations that have an interest in and concern for these activities. ${ }^{54}$

This committee discussed the subject heading code at the 1988 ALA Midwinter Meeting. It was noted that no one had made a formal proposal to either LC or ALA. ${ }^{55}$ The group again discussed the code at the 1988 ALA Annual Conference in July, but no proposal for a subject heading code was adopted ${ }^{56}$

A savvier advocate of the subject heading code might have tried to employ what Yukl calls "coalition tactics": "Mention credible people who support your proposal. . . . Bring someone along to help you in an influence attempt. . . . Get other people to provide evidence or an endorsement.... Ask for help from someone with higher authority." ${ }^{, 57}$ Perhaps the latter is most crucial. In a 2010 telephone interview with the author, Intner recalled that Studwell was not involved with ALA committees, and was not a familiar face to members of the SAC. As a peripheral member of the network of cataloging agencies, Studwell's voice was easily disregarded by those with gatekeeping responsibilities. Had he attempted to work with members of SAC to introduce a resolution regarding a subject heading code, his ideas would at least have had some formal notice.

Negative reaction to the idea of a subject code in print came from Reynolds, who published "In Theory There is No Solution: The Impediments to a Subject Cataloging Code" in July $1989 .{ }^{58}$ Unlike other papers on the topic published at the time, Reynolds did not reference Studwell's proposal. Instead, she noted that subject catalogers had yet to agree on the purpose of subject headings, let alone principles for their formulation. Her assertion that the code was needed, but could not be attained, led her to disdain efforts to create a code. She did, however, advocate incremental steps to improve subject headings - many of which were similar to those proposed by Studwell in his two series on subject headings, "Subject Suggestions" and "Cataloging Forum: Subject Access Theory" (see below).

\section{Further Development of Studwell's Ideas}

Studwell remained quite active in his quest to establish a subject heading code. In early 1988, he published (in collaboration with Paule Rolland-Thomas) "The Form and
Structure of a Subject Heading Code. ${ }^{י 59}$ This paper laid out, for the first time, Studwell's conception of the practical necessities of a subject heading code. The authors envisioned two sections. The first section, containing the rules of subject cataloging, would have three parts: the theory behind LCSH (including logic and structure of headings, and grammar), specific rules applying to subject headings (including how and when to use secondary headings), and a series of subparts consisting of special rules for subject areas such as art or music. The second, and main, section would consist of lists of headings and subdivisions, with notes on their use-it would be loose-leaf and updated regularly.

In 1988, Studwell began a series of "Subject Suggestions" in Cataloging and Classification Quarterly relating to subject headings for various disciplines, including geography, science, literature, language, art, and social sciences. Through these pieces, Studwell brought attention to specific shortcomings in LCSH, and he developed concrete proposals to address those flaws. The "Subject Suggestions" included criticism of faulty logic in subject heading structures, omissions of important subdivisions, and missing cross-references. They were, in essence, samples of the type of work that Studwell planned to use in formulating a subject heading code.

Studwell also continued to explicate the advantages of a subject heading code in a series of papers in Technicalities. These papers ranged from those that explained the need for a code in terms of "user-friendly subject access" to dissecting resistance to the code as "Codeophobia." ${ }^{60}$ They included a regular column in Technicalities, "Cataloging Forum: Subject Access Theory," that ran from September 1989 to August 1993, and covered LCSH (and the subject heading code in particular) through the developments of the early 1990s. Read together with the "Subject Suggestions," the columns are a compendium of most of the information considered necessary by Studwell to assemble a subject heading code.

\section{Simultaneous Developments in Subject Headings}

From 1989 to 1991, the cataloging community made progress toward a more rational method of formulating and assigning subject headings; that it occurred simultaneously with Studwell's continuing efforts to call attention to his plan is noteworthy. An important step was the publication of "A Subject Cataloging Code?" by Lois Mai Chan in 1989. While Chan disagreed with Studwell's call for a complete set of rules (her feeling was that the SCM covered most contingencies), she agreed on the need for a statement of principles. Her tone was chary about the feasibility of the enterprise, however: 
Who will develop the code? There appear to be two alternatives: (1) outside of the Library of Congress or (2) by the Library of Congress. . . . It would be unfortunate if either group takes on the responsibility without participation from the other. ... The question is, then, who will take primary responsibility for the overall planning and code development? Three criteria should be considered in determining the vesting of responsibility: (1) available resources, (2) efficacy and efficiency, and (3) implications for implementation. In applying these criteria, the experiences in the development of AACR2 could be used as a point of reference. ${ }^{61}$

The fact that a librarian of Chan's prominence as one of the preeminent theorists and teachers of cataloging chose to write on the subject heading code is an indicator that the idea had gained some intellectual currency. Her note about using the development of AACR2 as a model might have given Studwell some important political direction, which he failed to follow.

Many developments related to a subject heading code followed in 1990; some were Studwell's work, and others came from LC or ALA. Studwell published a 114-page monograph, Library of Congress Subject Headings: Philosophy, Practice, and Prospects, which sold about nine hundred copies around the world, according to a 2006 letter Studwell wrote to the author. ${ }^{62}$ In the monograph, Studwell addressed issues raised by critics of a subject heading code, and developed thirty-two "Principles Relating to the LCSH System" (in structure, terminology, documentation and other topics). Some are principles derived from actual use of LCSH, but others are proposals for a logical basis from which to construct subject headings. He also developed fifteen "Principles Relating to the Application or Interpretation of LCSH," including considerations of display in online catalogs.

Studwell's monograph was his best chance at mastering the technique Yukl calls "rational persuasion": "logical arguments and factual evidence that a request or proposed change is important for the organization and feasible for the target person." ${ }^{\circ 3}$ Combined with political connections, it is the most powerful technique for organizational change. However, it requires "persuasive skill, expertise about the request or proposal, and credibility with target persons. ${ }^{, 64} \mathrm{In}$ Studwell's case, his failure to refer to the work of others who had preceded him regarding subject headings undermined his claims to credibility.

Some of the "principles" that Studwell suggested should form the basis of a subject heading code included the following: "Consistency is the single most important characteristic in subject cataloging"; "Structural elements in LC subject headings must be simple"; "Rival headings' must be eliminated from LC subject headings"; and "Consistent and clearly understood terminology must be used in LC subject headings. ${ }^{.65}$ These are fine practical suggestions for the format and structure of LCSH; however, they fail to address the semantic issues that should inform principles of any code for organizing information.

Considering Chan's and Studwell's recommendations that a subject heading code proceed along the lines of AACR, one would surmise that a statement of principles for subject access would resemble the "Paris Principles" for author and title entry that were the foundation of both editions of AACR. The Paris Principles provide an explanation of "Functions of the Catalogue" ("The catalogue should be an efficient instrument for ascertaining whether the library contains a particular book") and "Structure of the Catalogue" "To discharge these functions the catalogue should contain at least one entry for each book catalogued") and clarify when a particular form of entry should be chosen under which circumstances. ${ }^{66}$ Studwell's "principles" articulate nothing at such an elemental level, and they seem uninformed by the work of Charles Cutter, whose notions of "specific entry" and "direct entry" form the basis of any discussion about subject access. Later scholars who elaborated on Cutter's work, such as Pettee, Haykin, Dunkin, and Miksa, are also absent from Studwell's book.

Studwell's attempt to elevate practical matters to the level of principles was criticized by reviewers. Rinehart wrote, "The book seems peculiarly limited in that Studwell makes little or no acknowledgement of the contributions of history in the development of subject headings; no work of Charles Cutter appears even in the general bibliography, which is described by the author as 'good background material on the subject." Salmond commented that by concentrating on a list of technical gripes instead of first principles "it fails to convince that a philosophically-based code of subject cataloging is a possibility, or even a good idea." ${ }^{\circ 7} \mathrm{By}$ contrast, an endorsement came from Schnelling, who wrote, "if LCSH are improved, along the principles outlined and summarized by Studwell (and by the authors cited in the book), LCSH will become an instrument of subject cataloguing feasible in the online age and rendering the investment that goes into it rewarding." ${ }^{" 68}$

Although Studwell hoped his book would serve as "a collegial attempt to help improve the understandability and clarity of the system . . . and in other ways make the Library of Congress subject heading system and its application of even greater value to the cataloger and the user," it seems to have largely been ignored in the scholarly debate about LCSH. $^{69}$ Of seventeen citations to the book recorded in Google Scholar on July 23, 2013, nine of them were in Studwell's own later papers. A limiting factor on the effectiveness of rational persuasion is "perceived expertise and credibility"; by failing to engage subject heading research at its intellectual foundations, Studwell undermined his own 
credibility as a proponent for change. ${ }^{70}$

With the publication of his book, Studwell felt progress had been made toward a code. In two papers published in early 1990, he summarized the state of the movement for a code: ALA announced a major conference on the code for its Annual Conference in June, literature reviews had covered the topic for the first time, and LC promised to publish a work covering the principles underlying LCSH. Studwell stated that the library community was at a crossroads: either it could make a strong push to work collectively to create a code, or else it must settle for the SCM. ${ }^{71}$ Studwell presented papers at the Illinois Library Association and the Michigan Library Association in 1990, but his largest audience (more than six hundred people) was at the 1990 ALA Annual Conference.

The 1990 Annual Conference assembled some eminent voices to speak for a subject code. Among the speakers were Michael Gorman (editor of AACR2 and later president of ALA; at the time he was Dean of Library Services at the Henry Madden Library, California State University, Fresno); Mary Dykstra (a critic of the syndetic structure of LCSH and then Director of the School of Library and Information Studies at Dalhousie University); and Liz Bishoff (an authority on controlled vocabulary and later president of the Association for Library Collections and Technical Services, then Manager for Cataloging and Database Services at OCLC). Again, coalition tactics were being used to "influence the target" decision-makers; however, the absence of any speakers from LC made this tactic less effective. ${ }^{72}$

Studwell himself spoke at the conference; besides summing up his arguments published over the previous years, he made a passionate personal plea:

In retrospect, I view my particular function in the movement toward a subject code to be somewhat similar, in a very minor way, to Martin Luther's role in the Reformation. At first Luther was just a local parish priest who was dissatisfied with policies and practices of the Catholic Church. At first I was just a local principal cataloger dissatisfied with the policies and practices of LC subject headings. Luther posted his 95 theses on the door of his church in Wittenburg in 1517. I published my seminal article on the subject code in Cataloging and Classification Quarterly, in 1985. After these initial probes, the two challenges to authority steadily grew and grew.

At a certain point, Luther was confronted by Church officials and was asked to back down on his efforts to reform. Luther, in one of the great moments in history, declared that his activities would continue and boldly proclaimed, "Here I stand!' Like Luther, I too can say, 'Here I stand,' ready to devote my time, energy, and intellect towards continuing improvement and codification of LC subject headings. All of you out there should also, in similar manner, stand up for the subject code. Onward! ${ }^{73}$

Aside from presenting a misunderstanding of Luther's pre-Reformation career-not simply a parish priest, he was the Chair of Biblical Theology at the University of Wittenburg-Studwell made a jumble of his attempt at the tactic of "inspirational appeal." enthusiasm and commitment by arousing strong emotions and linking a request or proposal to a person's values and ideals" is most successful when it appeals to the audience's self-image and links to a clear and appealing vision. ${ }^{75}$ Librarians are often self-sacrificing, but martyrdom for the sake of an improved subject access system is probably beyond the average librarian's notion of a worthy death. Studwell's self-aggrandizing manner limited the appeal of his vision; although he claimed to be founder of a "movement," he was a marginal participant in the interorganizational network who had failed to make the connections necessary to become influential in the decision-making hub. ${ }^{76}$

Studwell's credibility may have been undermined to some extent by his determination to make a "movement" out of normal scholarly courtesies. Consider this announcement from 1988:

As a result of the November 1987 article, correspondence with two interested and supportive individuals was transacted. . . . The most concrete result was the development of an article on LC subject headings for geology. ... As a result of other articles and a paper dealing with a comprehensive theoretical code of LC subject headings, the following developments have occurred: [here he lists the discussion of the topic at various meetings and the production of more articles. $]^{77}$

An announcement made in 1991 states:

All the articles, speeches, books, and meetings in recent years appear to be bearing potential fruit. The first clear written sign of it was possibly a May 17, 1990 letter received by this author. Sent by Lucia J. Rather, Director for Cataloging at LC, the letter was in response to an inquiry. Among other information, Rather confirmed an earlier oral pronouncement at ALA Midwinter, January 1990, about Lois Chan being asked to prepare "a document describing subject heading principles and practices as is currently carried out at the Library of Congress." . . . More important than 
these announcements was the specific language used by Rather. The opening sentence, "Thank you for your letter of March 27 regarding work on the development of an LC subject heading code," was quite revealing. It could easily be interpreted as LC starting to edge toward the construction of a subject code although such an action was not explicitly stated.

Also of great interest was Rather's statement concerning the work to be done by Chan, "We plan to use her document as input to new investigations regarding the future of LCSH." It clearly suggests that LC is seriously considering substantial and meaningful changes to LC subject heading policy and practice. One of the possibilities, of course, is the development of a comprehensive all purpose theoretical subject heading code. . . . Another statement by Rather reinforces this apparent psychological outlook by LC. Her final sentence was "I appreciate your interest in this area which is of concern to us all." The key words here are "concern" and "us all." Rather is thereby indicating both the importance of the matter and the sharing of the handling of the problem between LC and others. ${ }^{78}$

Studwell probably misled himself with this reading of Rather's letter. Pietris, in a 2010 email to the author, reported that "we never thought that a separate body should write a subject heading code if that code was to guide the headings developed by and applied at the Library of Congress - the logical group to write such a code would be LC itself. . . I believe that Mr. Studwell read more into his communications than was warranted."

\section{LC Makes Changes}

Studwell's work and that of others regarding improved subject headings did not occur in a vacuum. In November 1990, LC published Library of Congress Subject Headings: Principles of Structure and Policies for Application by Lois Mai Chan. ${ }^{79}$ In sixty-five pages, Chan outlined fifteen principles of heading construction and eight general guidelines for assigning subject headings, along with many rules for special materials. The work is thorough, yet substantially supports Studwell's contention that there is no firm set of principles. Most principles have caveats indicating that, while a principle usually applies to subject headings, certain exceptions (sometimes too numerous to list) exist.

In December 1990, "there followed a widely disseminated request by Glen Zimmerman, Director for Technical Processes Research at LC, for comments and responses to several position papers about LC subject headings." ${ }^{\text {80 }}$ In addition, LC announced a conference on the use of subject subdivisions, and commissioned several technical proposals to improve subject subdivisions. The conference, held at Airlie, Virginia, in May 1991, recommended six changes to the use of subject subdivisions, and LC agreed to a trial run for five years. ${ }^{81}$ At the end of the trial, it was agreed to accept all the changes. ${ }^{82}$

The adjustments in subdivision rules were a major step toward rational assignment of subject headings; all categories of subdivisions were assigned a standard order within a subject heading, allowing users and catalogers to consistently predict how a heading would be structured. Studwell called it "nothing but good news" but at the same time managed to claim the shift of policy as "one which this author has been suggesting in writing since 1982." ${ }^{\circ 3}$ After the announcement of changes arising from the Airlie conference, LC continued to make smaller changes to individual subject headings to incrementally make LCSH more rational; many of the changes paralleled ideas that had been mooted during the discussion of a subject heading code.

Studwell's role in these developments is debatable. Building on a literature survey about the topic of a subject headings code, in which more than 50 percent of the writings were his own, Studwell presented the innovations as responses to recent publications on the topic ${ }^{84}$ However, one might see them as a continuation of LC's ongoing efforts to explicate LCSH, which had been happening since the 1960s. Chan, while acknowledging in a 2005 book that her monograph was developed "perhaps in response to pressure," wrote to the author in 2010 that the commissioning and publication of the book were Rather's decision. ${ }^{85}$

Studwell was hopeful that these developments would lead to a formal subject heading code. In the summer of 1991, he wrote that many communications from LC had encouraged him in his efforts, and that he believed a strong push from the library community would cause LC to commit to creating a code shortly. ${ }^{86}$

\section{Stagnation of Studwell's Activism toward a Code}

Over the next few months, Studwell's papers became more pessimistic. He wrote that the movement for a subject heading code must succeed soon, or else library patrons would reject the entire scheme. ${ }^{87}$ Throughout 1991 and 1992, Studwell continued to write about the theory and practice of subject cataloging, with an emphasis on the subject heading code, although other authors were not addressing the topic as often. In the spring of 1992, he expressed his frustration at the lack of positive movement by LC toward a code. Despite what he had perceived as encouraging signs in 1990 and 1991, there had been no follow-up in terms of 
establishing a committee to consider a subject heading code, or even in appointing an individual to serve as an intellectual leader, such as Seymour Lubetzky had done for AACR. Studwell was bold enough to publicly offer his services in that capacity ("providing excellent credentials"), but was politely rebuffed. ${ }^{88}$ By the summer, he had concluded that LC, like many large institutions, was affected by its bureaucratic culture: it suffered on the one hand from reluctance to adopt bold new measures for fear of criticism, and on the other from a resistance to outsiders' participation in decision-making. ${ }^{89}$

In his own writings, however, Studwell provides evidence that he may have imparted his own wishful thinking to the likely outcomes of the process underway at LC:

In response to an inquiry from me, primarily about whether LC planned to continue the path toward revision and improvement of LC subject headings, Glenn A. Zimmerman ... wrote the following in a letter of August 12, 1991: "Although it is a bit premature to give you specifics, I can say that we are continuing the trend toward change at LC. ... We have received a great deal of input from you and many others 'in the field' and are at a stage where we will be taking some actions. Our plate is rather full now, and it is time to deal with the many items on it."

Zimmerman's vague promise of "change" was elevated in Studwell's columns to a hope that "LC takes the high road of a formal comprehensive all-purpose theoretical subject heading code accompanied by the appropriate adjustment and modification to LC headings and their application." ${ }^{90}$

In Studwell's mind, it was a moment of crisis in which the future of LCSH was being decided by bureaucratic inertia. ${ }^{91}$ As noted by Pietris in her letter to the author, however, it seems that LC had never seriously considered a complete subject headings code; their internal deliberations concluded that continued improvement of the SCM, accompanied by changes to the subdivision structure, was sufficient to meet the future needs of LCSH users.

As LC persisted in its silence regarding further action, Studwell was a "lone voice" on the topic of a subject headings code by 1992, and Stone declared that the movement for a code was "virtually dead."92 Studwell refused to acknowledge that the code would not be achieved, and he continued not only to write his Technicalities column, but to give talks and to write papers urging map librarians and music librarians to consider a subject heading code. ${ }^{93} \mathrm{By}$ fall 1993, he noted that LC continued to stand by the SCM, which appeared to be more evidence that LC was not seriously interested in improving subject access. Yet he held out hope that the public sentiment for government reform then being expressed by the general populace would also bring reform of subject access. His were the only papers on the subject heading code that year, however. ${ }^{94}$

\section{Studwell Looks Back}

In the summer of 1994, Technical Services Quarterly published a paper with the shocking title, "Who Killed the Subject Code? ${ }^{י 55}$ In it, Studwell-while refusing to categorically accept that no subject heading code would ever be created-responded to Stone's assertion that the movement was virtually dead by conducting an inquest. Looking back on his efforts at reform, Studwell took heart from the numerous changes in LCSH (not limited to the subdivisions conference, but including changes in individual headings, cross-references and structure) that his colleagues and he had spurred LC to adopt, and he noted that other authors continued to call for standardization of LCSH, even if not explicitly on Studwell's terms. ${ }^{96}$

Looking over the reasons for the failure of the library community to adopt a code, he found some blame for LC, for ALA ("although the code was discussed at several SAC meetings, this group did not follow through in an effective manner"), for online catalogs (and the illusion that keyword searching eliminates the need for bibliographic control), for himself (poor health made him unable to draft a proposed code), and most of all for "professional ignorance, apathy, and negativism. ${ }^{" 97}$ Despite the setbacks he encountered, Studwell never wrote any more bitterly than this.

A year later, Studwell marked the tenth anniversary of his first paper on the subject code ( "Why Not an 'AACR' for Subject Headings?") in "Ten Years After the Question: Has There Been an Answer?" ${ }^{\text {?98 }}$ He credited good timing for the interest his 1985 paper generated (it came long enough after AACR2 for the library community to have adjusted to the changes in descriptive cataloging), and took comfort in the great progress toward more standardized subject headings that had been achieved; despite that, he continued to call for a subject heading code.

Studwell reserved his last words on the subject heading code for a pair of 1997 papers. ${ }^{99}$ Nearing retirement, he noted research showing that libraries were failing to keep up with the many piecemeal changes to LCSH doled out over the years by LC; perhaps a single statement of principles, and the accompanying wholesale changes (such as occurred with AACR2) would have better served subject access. He concluded, "By mostly bypassing the issue of written principles to guide the world's most important subject access system, LC has, in effect, hoped that the problem, like a bad dream or an undesirable person, would just go away. But no matter how much LC, this author, and others who opposed the idea, may try to ignore the lack of guiding principles for 
LCSH, the specter seems to remain." ${ }^{100}$

It is interesting to note how, in Studwell's estimation, organizational change should have occurred. Studwell proposed, and waited for, SAC, LC, or other librarians to take action. Despite the clear message from LC that proposals were required through the proper channels, Studwell never seemed to acquire the knowledge that "power is a relational phenomenon." 101 Yukl advises that "it is very helpful to have sympathetic representatives in key administrative positions or on decision groups." 102 Despite Studwell's furious pace of activity, he never seemed to secure allies within LC.

Studwell's success in achieving a subject heading code was limited by his outsider status. This author has had the privilege, as a member of SAC, of witnessing the implementation of Library of Congress Genre/Form Terms (LCGFT) during the years 2011-2013. While many factors were important in the success of this idea, perhaps the most crucial was the presence of an LC librarian on the project team; she has direct access to LC's decision-makers and could easily communicate SAC members' concerns to LC administrators. The presence of a large group of librarians working jointly on this project is another factor in its success; as Studwell noted, he largely worked alone and was unable to deliver a complete draft of a subject headings code.

Studwell's prolixity may have, in the end, damaged rather than enhanced his credibility as a critic. By issuing endless columns, papers, and presentations, he failed to ground his critiques in the deep knowledge and scholarly apparatus that are most indicative of intellectual authority. In addition to his failure to cite or refer to foundational thinkers in subject access, his work was subject to criticisms such as Fischer's comment in a literature review that states, "His publications tend to be somewhat redundant in their arguments," and John Hostage's letter to the author noting, "The footnotes in his articles almost always cited other articles by him. It would have increased his credibility if he had cited the work of others more."103

\section{Conclusion}

William E. Studwell never achieved his goal of the adoption of a subject headings code. Nonetheless, he continued to write on librarianship throughout his career and well into his retirement. He took solace that "the overall improvement to LCSH that occurred during the late 1980s and early 1990, which came to pass largely because of pressure from many librarians outside LC, including me," had alleviated some of the pressing problems he identified early in his campaign. ${ }^{104}$

Studwell was credited by Shubert with "attracting the attention of the American library community to the need for a 'comprehensive, all-purpose theoretical code for Library of
Congress subject headings." ${ }^{105}$ However, his own goals were much broader - to see the adoption of such a code. In the end, no such code has been adopted. In correspondence to the author, Studwell wrote in 2006,

Various persons told me I was crazy or delusional or something similar for trying to change the philosophy and practices of the world's largest library, and a U.S. federal agency to boot. But although the final goal was not achieved, I firmly believe that at least half of my mini-goals were quietly and tacitly enacted by LC in the late 1980s and 1990s. . . . LCSH is much better than it was about twenty-five years ago, that is, before I began to "attack" the LCSH establishment.

Although it was promulgated after Studwell's retirement, the Functional Requirements for Subject Authority Data (FRSAD): Final Report is a document that may point to a future subject heading code. Its purpose is to "produce a framework that will provide a clearly stated and commonly shared understanding of what the subject authority data/record/file aims to provide information about, and the expectation of what such data should achieve in terms of answering user needs." 106

Studies of interorganizational networks such as the US cataloging community have consistently found that when decision-making occurs at the hub of the network, peripheral participants must establish ties to those in the center if they hope to wield influence. Many important techniques for organizational change require the acquiescence of those in power; without it, all requests for change can be deferred by bureaucratic gatekeepers.

Studwell, it seems, never learned these lessons-he failed to observe the bureaucratic niceties of submitting a proposal through the SAC. For all his admirable traits of doggedness, idealism, and productivity, his neglect of the formalities required by the network's lead organization prevented his proposals from receiving serious consideration; and his absence of allies within LC was more damaging to the prospects for his plan. For those seeking to be change agents within the library community, Studwell's story provides numerous lessons: it is best to be strategic, bureaucratic, and credible-and ideally, it is strategic to position oneself at the hub of the network rather than the margins. While Studwell considered himself as a Luther of librarianship, perhaps he was more a William Jennings Bryan - a man whose "ability to lose worthy causes with unpersuasive arguments was uncanny." 107 Studwell was a persistent advocate of change whose ideas certainly were part of an ongoing conversation between librarians that led to improvements in LCSH. His remarkable record of scholarship is a testament to his curiosity and drive, and the 
ultimate frustration of his campaign for a subject headings code is an object lesson in navigating interorganizational networks.

\section{References and Notes}

1. George Bernard Shaw, Maxims for Revolutionists in Man and Superman: A Comedy and a Philosophy (1950; repr., New York: Brentano’s, 1938), 238.

2. Quoted in Milton L. Rakove, We Don't Want Nobody Nobody Sent: An Oral History of the Daley Years (Bloomington: Indiana University Press, 1979), 318.

3. William E. Studwell, "Who Killed the Subject Code?" Technical Services Quarterly 12, no. 1 (1994): 39.

4. Patricia Bradshaw and Jaap Boonstra, "Power Dynamics in Organizational Change: A Multi-Perspective Approach," in Dynamics of Organizational Change \& Learning, ed. Jaap J. Boonstra, 279-300 (Hoboken, NJ: Wiley, 2004).

5. Mark Ebers, "Explaining Interorganizational Network Formation," in The Formation of Interorganizational Networks, ed. Mark Ebers (New York: Oxford University Press, 1997), 4.

6. LCSH, of course, is not the only vocabulary in use by libraries; the Sears List of Subject Headings and Medical Subject Headings are both popular. But LCSH dominates subject cataloging for academic, research and many public libraries.

7. For examples, see Sanford Berman, The Joy of Cataloging: Essays, Letters, Review \& Other Explosions (Phoenix, AZ: Oryx, 1981).

8. Walter W. Powell, "Neither Market Nor Hierarchy: Network Forms of Organization," in Research in Organizational Behavior, vol. 12, ed. Barry M. Staw and L. L. Cummings (Greenwich, CT: JAI, 1990), 323.

9. Ibid., 325 .

10. Keith G. Provan, Amy Fish and Joerg Sydow, "Interorganizational Networks at the Network Level: A Review of the Empirical Literature on Whole Networks," Journal of Management 33, no. 3 (2007): 503.

11. Keith G. Provan and Patrick Kenis, "Modes of Network Governance: Structure, Management and Effectiveness," Journal of Public Administration Research \& Theory 18, no. 2 (2008): 235.

12. Gordon Müller-Seitz, "Leadership in Interorganizational Networks: A Literature Review and Suggestions for Future Research," International Journal of Management Reviews 14, no. 4 (2012): 430.

13. Chris Huxham and Siv Vangen, "Leadership in the Shaping and Implementation of Collaboration Agendas: How Things Happen in a (Not Quite) Joined-Up World," Academy of Management Journal 43, no. 6 (2000): 1160.

14. Daniel J. Brass et al., "Taking Stock of Networks and Organizations: A Multilevel Perspective," Academy of Management Journal 47, no. 6 (2004): 795-817.

15. Bradshaw and Boonstra, "Power Dynamics in Organizational
Change," 285.

16. Cynthia Hardy and Stewart Clegg, "Power and Change: A Critical Reflection," in Dynamics of Organizational Change \& Learning, ed. Jaap J. Boonstra (Hoboken, NJ: Wiley, 2004), 238.

17. Gary Yukl, "Interactions in Organizational Change: Using Influence Tactics to Initiate Change," in Dynamics of Organizational Change and Learning, ed. Jaap J. Boonstra (Hoboken, NJ: Wiley, 2004), 309.

18. Charles Coffin Jewett, Smithsonian Report on the Construction of Catalogues of Libraries, and Their Publication by Means of Separate, Stereotyped Titles: With Rules and Examples (Washington: Smithsonian Institute, 1853); Mercantile Library of Boston, Catalogue of the Mercantile Library of Boston (Boston: Mercantile Library Association; printed by John Wilson and Son, 1854); Ezra Abbot, "Mr. Abbot's Statement Respecting the New Catalogues of the College Library," in Report of the Committee of the Overseers of Harvard College Appointed to Visit the Library for the Year 1863: Together with the Accompanying Documents (Boston: The College, 1864); Charles A. Cutter, "Rules for a Printed Dictionary Catalog," in US Bureau of Education, Public Libraries in the United States: Their History, Condition, and Management (Washington: Government Printing Office, 1876); Frederick Beecher Perkins, San Francisco Cataloging for Public Libraries: A Manual of the System Used in the San Francisco Free Public Library (San Francisco: The Library, 1884); Melvil Dewey and Mary Salome Cutler, Rules for Author and Classed Catalogs: As Used in Columbia College Library, with 52 Facsimiles of Sample Cards (Boston: Library Bureau, 1888); Klas August Linderfelt, Eclectic Card Catalog Rules (Boston: Charles A. Cutter, 1890).

19. W. C. Lane, "Cataloging," in Abstracts of Papers, etc.: World's Fair Congress and Chicago Conference, July 13-22, 1893, special issue, Library Journal (July 1893): 238-40.

20. Terry M. Heisey, "Early Catalog Code Development in the United States, 1876-1908," Journal of Library History 11, no. 3 (1976): 218-48.

21. Alva T. Stone, "The LCSH Century: A Brief History of the Library of Congress Subject Headings, and Introduction to the Centennial Essays," Cataloging \& Classification Quarterly 29, no. 1-2 (2000): 1-15.

22. Martha M. Yee, "Wholly Visionary: The American Library Association, the Library of Congress, and the Card Distribution Program," Library Resources \& Technical Services 53, no. 2 (2009): 68-78.

23. Paul Edlund, "A Monster and a Miracle: The Cataloging Distribution of the Library of Congress, 1901-1976," Quarterly Journal of the Library of Congress 33, no. 4 (1976): 383-421.

24. Paul Dunkin, "From Pig to Man," in Toward a Theory of Librarianship: Papers in Honor of Jesse Hauk Shera, ed. Conrad H. Rawski, 339-49 (Metuchen, NJ: Scarecrow, 1973).

25. Kathryn Luther Henderson, "Treated with a Degree of 
Uniformity and Common Sense': Descriptive Cataloging in the United States, 1876-1975," Library Trends 25, no. 1 (1976): 232.

26. Doralyn J. Hickey, "Subject Analysis: An Interpretive Survey," Library Trends 25, no. 1 (1976): 277.

27. J. C. M. Hanson, "The Subject Catalogs of the Library of Congress," Bulletin of the American Library Association 3 (1909): 385-97.

28. Sally Jo Reynolds, "In Theory There is No Solution: The Impediments to a Subject Cataloging Code," Library Quarterly 59 (1989): 224; see also Edith Scott, "J. C. M. Hanson and His Contribution to Twentieth-Century Cataloging" (PhD diss., University of Chicago, 1970); Francis L. Miksa, The Subject in the Dictionary Catalog from Cutter to the Present (Chicago: ALA, 1983).

29. John R. Likins, "Subject Headings, Silly, American-20th Century-Complications and Sequelae-Addresses, Essays, Lectures," Technical Services Quarterly 2, no. 1-2 (1985): 3-11.

30. For a review of literature critical of LCSH, see Monika Kirtland and Pauline Cochrane, "Critical Views of LCSHLibrary of Congress Subject Headings: A Bibliographic and Bibliometric Essay," Cataloging \& Classification Quarterly 1, no. 2-3 (1982): 71-94; Steven Blake Shubert, "Critical Views of LCSH Ten Years Later: A Bibliographic Essay," Cataloging \& Classification Quarterly 15, no. 2 (1992): 37-97; and Karen S. Fischer, "Critical Views of LCSH, 1990-2001: The Third Bibliographic Essay," Cataloging \& Classification Quarterly 41, no. 1 (2005): 63-109.

31. Wyllis E. Wright, ed., Vatican Library: Rules for the Catalog of Printed Books (Chicago: ALA, 1948).

32. David J. Haykin, Subject Headings: A Practical Guide (Washington, DC: Government Printing Office, 1951); Library of Congress, Subject Cataloging Division, Library of Congress Subject Headings: A Guide to Subdivision Practice (Washington, DC: The Library, 1981); Library of Congress, Subject Cataloging Division, Subject Cataloging Manual: Subject Headings (Washington, DC: The Library, 1984).

33. Richard S. Angell, "Library of Congress Subject HeadingsReview and Forecast," in Subject Retrieval in the Seventies: New Directions. Proceedings of an International Symposium Held at the Center of Adult Education, University of Maryland, College Park, May 14 to 15, 1971, ed. Hans Wellisch and Thomas D. Wilson (Westport, Conn.: Greenwood, 1972), 161; see also Stone, "The LCSH Century."

34. Barbara B. Tillett, "Catalog It Once for All: A History of Cooperative Cataloging in the United States Prior to 1967 (Before MARC)," Cataloging \& Classification Quarterly 17, no. 3-4 (1993): 3-38.

35. Allen Kent, "The On-Line Revolution in Libraries, 1969,"American Libraries 10, no. 6 (1979): 339-42; Edwin E. Olson, Russell Shank, and Harold A. Olsen, "Library and Information Networks," Annual Review of Information
Science \& Technology 7 (1972): 279-321.

36. Beacher Wiggins, "The Program for Cooperative Cataloging," in Proceedings of the Taxonomic Authority Files Workshop, Washington, D.C., June 22-23, 1998, ed. Stanley D. Blum (San Francisco: California Academy of Sciences, 1998), accessed July 23, 2013, http://researcharchive.calacademy. org/research/informatics/taf/proceedings/wiggins.html.

37. Ibid.

38. John Budd and Charles A. Seavey, "Characteristics of Journal Authorship by Academic Librarians," College and Research Libraries 51, no. 5 (1990): 463-70; Ann C. Weller, Julie M. Hurd, and Stephen E. Wiberley, "Publication Patterns of US Academic Librarians from 1993 to 1997," College \& Research Libraries 60, no. 4 (1999): 352-62.

39. Kathryn Luther Henderson, "Subject Headings," in Encyclopedia of Library History, ed. Wayne A. Wiegand and Donald G. Davis Jr. (New York: Garland, 1994), 605.

40. William E. Studwell, "Curriculum Vitae," Office of the Dean of University Libraries, Northern Illinois University; Dorothy E. Jones, "William E. Studwell," Music Reference Services Quarterly 6, no. 4 (1998): 99-101.

41. Bob Herguth, "William Studwell," Chicago Sun-Times, December 14, 1994; Contemporary Authors (Farmington Hills, Mich.: Gale, 2002), s.v. "Studwell, William E."

42. Dorothy Kanwischer, "Subject Headings Trauma," Wilson Library Bulletin 49, no. 9 (1975): 651-54; Michael Pope, "Subject Headings Muddle," RQ 15, no. 2 (1975): 129-31; Hans H. Wellisch, "Poland is Not Yet Defeated, Or: Should Catalogers Rewrite History? With a Discourse on When Is an Island Not an Island?” Library Resources \& Technical Services 22, no. 2 (1978): 158-67; Patrick Wilson, "The End of Specificity," Library Resources \& Technical Services, 23, no. 2 (1979): 116-22; Gregor A. Preston, "Coping with Subject Heading Changes," Library Resources \& Technical Services 24, no. 1 (1980): 64-68; Likins, "Subject Headings, Silly, American"; David Henige, "Library of Congress Subject Headings: Is Euthanasia the Answer?" Cataloging \& Classification Quarterly 8, no. 1 (1987): 7-19; Mary Dykstra, "Can Subject Headings Be Saved?” Library Journal 113, no. 15 (September 15, 1988): 55-58.

43. William E. Studwell, "A Prose Ode to Sandy Berman from a Fellow Gadfly,” Technicalities 23, no. 5 (2003): 3.

44. William E. Studwell, "Library of Congress Subject Heading Period Subdivisions for Southeast Asia: Some Proposed Additions," Cataloging \& Classification Quarterly 2, no. 3-4 (1982): 31-43; William E. Studwell and Narindar K. Aggarwal, "Library of Congress Subject Heading Period Subdivisions for East Asia: Some Proposed Additions," Cataloging \& Classification Quarterly 3, no. 4 (1983): 65-78; William E. Studwell and Narindar K. Aggarwal, "Library of Congress Subject Heading Period Subdivisions for West Asia and the Near East in General: Some Proposed Additions," Cataloging \& Classification Quarterly 4, no. 1 (1983): 37-52; William E. 
Studwell and David A. Hamilton, "Library of Congress Subject Heading Period Subdivisions for Latin America: Some Proposed Additions," Cataloging \& Classification Quarterly 4, no. 3 (1984): 39-74; William E. Studwell, Elaine Rast, and Cheryl Felmlee, "Library of Congress Subject Heading Period Subdivisions for Africa: Some Proposed Additions," Cataloging \& Classification Quarterly 4, no. 4 (1984): 51-97; William E. Studwell, "Library of Congress Subject Heading Period Subdivisions for Australia, New Zealand and Selected World Islands: Some Proposed Additions," Cataloging \& Classification Quarterly 5, no. 3 (1985): 67-78; William E. Studwell and David A. Hamilton, "Library of Congress Subject Heading Period Subdivisions for Eastern Europe, Excluding the Soviet Union: Some Proposed Additions," Cataloging \& Classification Quarterly 6, no. 1 (1985): 39-60; William E. Studwell and David A. Hamilton, "Library of Congress Subject Heading Period Subdivisions for the Soviet Union: Some Proposed Additions," Cataloging \& Classification Quarterly 6, no. 3 (1986): 63-83; William E. Studwell, "Library of Congress Subject Heading Period Subdivisions for the History of Canadian Regions, Provinces, and Territories: Some Proposed Additions," Cataloging \& Classification Quarterly 7, no. 3 (1987): 121-26; William E. Studwell, "Library of Congress Subject Heading Period Subdivisions for the History of the Individual States of the United States: Some Proposed Additions," Cataloging \& Classification Quarterly 8, no. 1 (1987): 121-31.

45. Studwell and Hamilton, "Library of Congress Subject Heading Period Subdivisions for Latin America," 73.

46. Henry B. Van Hoesen, "Perspective in Cataloging, with Some Applications," Library Quarterly 14, no. 2 (1944): 102-3; Sanford Berman, "Proposed: A Subject Cataloging Code for Public School and Community College Libraries," HCL Cataloging Bulletin 39 (1979): 1-5.

47. William E. Studwell, "Why Not an AACR for Subject Headings?" Cataloging \& Classification Quarterly 6, no. 1 (1985): 3-9.

48. William E. Studwell, "Academic Libraries and a Subject Heading Code," Journal of Academic Librarianship 12, no. 6 (1987): 372; William E. Studwell, "Map Libraries and a Subject Heading Code," Information Bulletin (Western Association of Map Libraries) 18, no. 2 (1987): 157-58.

49. William E. Studwell, "The 1990s: Decade of Subject Access," American Libraries 18, no. 11 (1987): 958-59.

50. Mary K. D. Pietris, "LC: New Manual, Not Code, Needed," American Libraries 18, no. 11 (December 1987): 958.

51. Bradshaw and Boonstra, "Power Dynamics in Organizational Change,” 283.

52. Sheila S. Intner, "ASCR: The American Subject Cataloging Rules," Technicalities 8, no. 7 (1988): 5-7; Sheila S. Intner, "The Trouble with Harry: ASCR (Part 2)," Technicalities 8, no. 9 (1988): 5-7.

53. Arnold S. Wajenberg, "The Future of Cataloging Standards,"
Illinois Libraries 72, no. 6 (1990): 494-97.

54. American Library Association, Association for Library Collections and Technical Services, "CaMMS Subject Analysis Committee," last modified November 14, 2013, accessed November 15, 2013, www.ala.org/alcts/mgrps/camms/cmtes/ ats-ccssac.

55. "San Antonio Midwinter Report," RTSD Newsletter 13, no. 2 (1988): 9-15.

56. William E. Studwell, "Subject Heading Clearinghouse for Map Catalogers: A Follow-up," Western Association of Map Libraries Information Bulletin 20, no. 1 (1988): 22.

57. Yukl, "Interactions in Organizational Change," 313.

58. Reynolds, "In Theory There is No Solution," 224.

59. William E. Studwell and Paule Rolland-Thomas, "The Form and Structure of a Subject Heading Code," Library Resources \& Technical Services 32, no. 2 (1988): 167-69.

60. William E. Studwell, "User-Friendly Subject Access," Technicalities 8, no. 10 (1988): 10-11; William E. Studwell, "Codeophobia: Five Possible Reasons Why Some Persons Do Not Support a Theoretical Code for LC Subject Headings," Technicalities 9, no. 2 (1989): 13-14.

61. Lois Mai Chan, “A Subject Cataloging Code?” Cataloging d Classification Quarterly 10, no. 1-2 (1989): 199-202.

62. William E. Studwell, Library of Congress Subject Headings: Philosophy, Practice, and Prospects (Binghampton, NY: Haworth, 1990).

63. Yukl, "Interactions in Organizational Change." 309.

64. Ibid., 302.

65. Studwell, Library of Congress Subject Headings, 14, 15, 25, 38.

66. International Conference on Cataloguing Principles, "Statement of Principles," in Foundations of Cataloging: A Sourcebook, ed. Michael Carpenter and Elaine Svenonious (1961; repr. Littleton, CO: Libraries Unlimited, 1985).

67. Constance Rinehart, review of Library of Congress Subject Headings, by William E. Studwell, Library Resources d Technical Services 36 (1992): 248; Rachel Salmond, review of Library of Congress Subject Headings by William E. Studwell, Australian Library Review 9 (1992): 239.

68. Heiner M. Schnelling, review of Library of Congress Subject Headings by William E. Studwell, International Classification 19, no. 3 (1992): 166.

69. Studwell, Library of Congress Subject Headings, 6.

70. Yukl, "Interactions in Organizational Change," 308.

71. William E. Studwell, "More Developments in the Subject Headings Arena,"Western Association of Map Libraries Information Bulletin 21, no. 2 (1990): 100; William E. Studwell, "The Subject Code: Two Unanswered Questions," Library Resources \& Technical Services 34, no. 2 (1990): 228-30.

72. Yukl, "Interactions in Organizational Change," 303.

73. William E. Studwell, "A Subject Code: Do We Have One? Do We Need One?” Technicalities 10, no. 10 (1990): 15.

74. Heiko A. Oberman, Luther: Man between God and the Devil 
(New Haven, CT: Yale University Press, 2006), 161.

75. Yukl, "Interactions in Organizational Change," 302, 310-11.

76. The "seminal" article Studwell mentioned was, according to Google Scholar on July 23, 2013, cited only eight timessix of those by Studwell himself; however, Shubert, "Critical Views of LCSH Ten Years Later," 48, does credit him with sparking a wider discussion of the subject heading code in the cataloging community.

77. Studwell, "Subject Heading Clearinghouse for Map Catalogers: A Follow-up," 22.

78. William E. Studwell, "Something's Going on at LC; Or, A Code by any Other Name would Still be a Code," Technicalities 11, no. 7 (1991): 10-11.

79. Lois Mai Chan, Library of Congress Subject Headings: Principles of Structure and Policies for Application (Washington, DC: Library of Congress Cataloging Distribution Service, 1990).

80. William E. Studwell, "Will the Real Year of the Subject Code Please Stand Up?” Technicalities 11, no. 8 (1991): 4.

81. Martha O'Hara Conway, ed., The Future of Subdivisions in the Library of Congress Subject Headings System: Report from the Subject Subdivisions Conference (Washington, DC: Library of Congress, Cataloging Distribution Service, 1992)

82. "Library of Congress Five-Year Progress Report on Subject Subdivisions Conference Recommendations," Cataloging Service Bulletin 75 (Winter 1997): 47-53.

83. William E. Studwell, "Hallelujah and Hurrah! A Major Recommendation for Change in LC Subject Headings by the Subject Subdivisions Conference," Technicalities 11, no. 11 (1991): 13.

84. Studwell, "The Subject Code: Two Unanswered Questions," 228-30.

85. Lois Mai Chan, Library of Congress Subject Headings: Principles and Application, 4th ed. (Westport, CT: Libraries Unlimited, 2005), 11.

86. Studwell, "Something's Going on at LC," 10-11; Studwell, "Will the Real Year of the Subject Code Please Stand Up?" 4.

87. William E. Studwell, "Sumer and Consumer: More about the Future of LC Subject Headings," Technicalities 11, no. 9 (1991): 8-9; William E. Studwell, "Going Up Or Going Down? The Elevator Dilemma for LC Subject Headings," Technicalities 11, no. 10 (1991): 15-16; William E. Studwell, "Cutterism, Codism, and Consumerism: The Past, Present, and Future of LC Subject Access," Technical Services Quarterly 9, no. 1 (1991): 19-25.

88. William E. Studwell, "LC's Full Plate: A Time for DecisionMaking about LC Subject Headings," Technicalities 12, no. 4 (1992): 6; William E. Studwell, "Who Will be the Osborn and Lubetzky of Subject Cataloging? A Question of Leadership in LC Subject Heading Policy Making," Technicalities 12, no. 5 (1992): 15-16.
89. William E. Studwell, "Who's Afraid of the Subject Code?" Technicalities 12, no. 6 (1992): 9-10.

90. Studwell, "LC's Full Plate," 6.

91. William E. Studwell, "The Three-Pronged Fork in the Road: A Detective Mystery of the Twenty-First Century," Information Bulletin (Western Association of Map Libraries) 23, no. 1 (1991): 42-43; William E. Studwell, "Looking Back at the 1990s: Two Scenarios from the Future Concerning LC's Subject Access System," Technicalities 12, no. 7 (1992): 8-9.

92. Alva T. Stone, "That Elusive Concept of Aboutness: The Year's Work in Subject Analysis, 1992," Library Resources \& Technical Services 37, no. 3 (1993): 277-98.

93. William E. Studwell, "A Tale of Two Decades; Or, the Decline of the Fortunes of LC Subject Headings," Information Bulletin (Western Association of Map Libraries) 25, no. 2 (1994): 73-74; William E. Studwell and Dawn A. Ericksen, "Music Libraries and a Subject Heading Code," Music Reference Services Quarterly 1, no. 1 (1992): 73-75.

94. William E. Studwell, "LC's Head in the Sand; Or, Why the Subject Cataloging Manual is Not Enough," Technical Services Quarterly 10, no. 3 (1993): 45-50.

95. Studwell, "Who Killed the Subject Code?" 39.

96. Masse Bloomfield, "A Look at Subject Headings: A Plea for Standardization," Cataloging \& Classification Quarterly 16, no. 1 (1993): 119-23; Karen M. Drabenstott, "Period Subdivisions in the Library of Congress Subject Headings System: Some Thoughts and Recommendations for the Future," Cataloging \& Classification Quarterly 15, no. 4 (1992): 19-45.

97. Studwell, "Who Killed the Subject Code?" 38.

98. William E. Studwell, "Ten Years After the Question: Has there been an Answer?" Cataloging \& Classification Quarterly, 20, no. 3 (1995): 95-98.

99. William E. Studwell, "Ignore It and It Will Go Away: . . but It's Still there!” Technicalities 17, no. 4 (1997): 1; William E. Studwell, “"Much Ado about Little; Or, Why can't LC Produce a Set of Principles for LC Subject Headings?” Technicalities 17, no. 7 (1997): 19.

100. Studwell, "Ignore It and It Will Go Away," 13.

101. Bradshaw and Boonstra, "Power Dynamics in Organizational Change," 283.

102. Yukl, "Interactions in Organizational Change," 309.

103. Fischer, "Critical Views of LCSH, 1990-2001," 72.

104. Studwell, "Ignore It and It Will Go Away," 1.

105. Shubert, "Critical Views of LCSH Ten Years Later," 48.

106. Marcia Lei Zeng, Maja Žumer, and Athena Salaba, eds., Functional Requirements for Subject Authority Data (FRSAD): A Conceptual Model (Berlin: De Gruyter Saur, 2011).

107. Gerard N. Magliocca, The Tragedy of William Jennings Bryan: Constitutional Law and the Politics of Backlash (New Haven, CT: Yale University Press, 2011), 149. 